удК 343.98:343.137.5

DOI https://doi.org/10.32837/npnuola.v28i0.707

\author{
C. В. Харченко, А. С. Симчук
}

\title{
ЗАЛУЧЕННЯ ЗАКОННОГО ПРЕДСТАВНИКА У КРИМІНАЛЬНИХ ПРОВАДЖЕННЯХ ЗА УЧАСТЮ НЕПОВНОЛІТНІХ ОСІБ
}

Постановка проблеми. Статистика та спеціальні дослідження доводять, що за останні роки відбулися негативні зміни в структурі злочинності неповнолітніх, а саме збільшилась кількість тяжких злочинів за їх участю, а також збільшилася кількість неповнолітніх потерпілих. 3 огляду на ці обставини вкрай актуальною є проблема вдосконалення професійної майстерності працівників слідчих підрозділів та підрозділів дізнання Національної поліції, оволодіння новими науковими методами розслідування кримінальних правопорушень, вчинених окремою категорією осіб, перелік яких передбачений ст. 480 КПК України, а також відносно неповнолітніх потерпілих, за неухильного дотримання процесуальних норм.

Стан дослідження проблеми. Досліджуючи проблеми нормативно-правового регулювання проведення слідчих (розшукових) дій за участю неповнолітніх потерпілих, підозрюваних чи обвинувачених, варто враховувати, що зазначене питання розглядалося вітчизняними та зарубіжними вченими із різних галузей юриспруденціі: конституційного права, кримінології, кримінального процесу, юридичної психології. Окремим аспектам кримінального судочинства щодо неповнолітніх взагалі та низки пов'язаних з ним проблем присвятили свої роботи такі автори, як: В.М. Бурдін, О.І. Вінгловська, Є.М. Гідулянова, О.Х. Галімов, Л.Г. Голиш, А.Є. Голубов, Н.В. Греса, С.М. Зеленський, Л.Л. Канєвський, Г.К. Кожевніков, С.П. Коталейчук, О.О. Кочура, Н.М. Крестовська, О.С. Ландо, О.О. Левендаренко, В.В. Леоненко, Н.В. Малиш, І.С. Манова, Е.Б. Мельникова, Г.М. Міньковський, Г.М. Омельяненко, О.М. Павлик, А.Б. Романюк, В.А. Рибальська, Н.Ш. Сафін, В.М. Трубніков, В.В. Шимановський, Н.В. Шость, О.О. Юхно, А.О. Яровий, О.В. Ярош та ін. Безумовно, зазначені дослідження мають важливе значення для юридичної науки, але особливої актуальності набуває питання нормативно-правового регулювання проведення слідчих (розшукових) дій за участю неповнолітніх учасників кримінального провадження у наш час.

Актуальність теми дослідження. Ефективність розслідування кримінальних правопорушень, вчинених неповнолітніми, залежить певним чином від своєчасного та ефективного проведення слідчих (розшукових) 
дій. Проведення слідчих дій за участю неповнолітніх осіб додає особливого навантаження, що потребує від слідчого ретельної підготовки до іiі проведення і врахування додаткових обставин, зокрема вікових, психологічних та процесуальних, які вимагають залучення додаткових учасників, зокрема законних представників.

Інститут законного представництва неповнолітнього в сучасному кримінальному судочинстві обумовлений його призначенням. На думку законодавця, наявність законного представника у кримінальному процесі покликана посилити гарантії захисту прав і законних інтересів деяких категорій учасників кримінального судочинства. Необхідність посиленого захисту прав і законних інтересів деяких категорій осіб у кримінальному судочинстві обумовлена сформованими правовими і фактичними умовами.

Серед осіб, які потребують особливого захисту, законодавець виділяє неповнолітніх осіб. Незважаючи на наявність процесуального статусу цих осіб у кримінальному судочинстві, законодавець визнає значущість того факту, що всі неповнолітні особи, залучені у сферу кримінального судочинства, у силу вікових особливостей потребують додаткових гарантій своїх прав і законних інтересів. Законних представників законодавець відносить до тих спеціальних суб'єктів, які покликані виконувати цю функцію.

I хоча зазначені науковці зверталися до дослідження означеної тематики, проте залишається низка питань, які потребують вивчення. До того ж аналіз практики свідчить про те, що слідчі під час проведення слідчих (розшукових) дій за участю неповнолітніх осіб допускають певні недоліки, пов'язані з неповним дотриманням процесуальних вимог та рекомендацій щодо порядку їх проведення.

Метою та завданням статті $€$ вивчення нормативно-правового регулювання проведення слідчих (розшукових) дій за участю неповнолітніх осіб та характеристика механізму участі законного представника в кримінальному провадженні.

Виклад основного матеріалу. У сфері кримінального провадження весь хід і результати проведення кожної процесуальної дії або ухваленого рішення щодо кримінального провадження буде правомірним за дотримання правил, установлених кримінальним процесуальним законом [8, с. 227].

Основою для визначення порядку нормативно-правового регулювання порядку проведення слідчих (розшукових) дій за участю неповнолітніх осіб є Кримінальний процесуальний кодекс України. Серед осіб, які потребують особливого захисту в кримінальному процесі, законодавець виділяє неповнолітніх учасників кримінального провадження. Насамперед необхідно визначити коло суб'єктів, разом з якими залучаються законні представники. Так, якщо потерпілим, підозрюваним, обвинуваченим є неповнолітня особа, до участі в процесуальній дії разом з нею залучається їі законний представник. (ст. 44, 59 КПК України).

Незважаючи на наявність процесуального статусу неповнолітнього в кримінальному судочинстві, законодавець визнає значущість того факту, що всі неповнолітні особи, залучені в сферу кримінального судочинства в силу вікових особливостей потребують додаткових гарантій своїх прав і законних інтересів. Законних представників законодавець відносить до 
числа спеціальних суб'єктів, покликаних додатково виконувати функцію щодо захисту прав і законних інтересів неповнолітніх осіб.

Е.Б. Мельникова вважає, що участь законного представника неповнолітньої особи у кримінальному процесі пов'язана з такими обставинами, як неповна процесуальна дієздатність неповнолітнього, та з тим, що законний представник несе відповідальність за виховання й поведінку неповнолітнього [5, с. 86-87]. Участь законного представника неповнолітнього також сприяє повній та ефективній реалізації його прав й інтересів. Основне завдання законного представника полягає у наданні допомоги неповнолітньому та активній участі його у кримінальному судочинстві [7, с. 109].

У законі не зазначено перелік осіб, які не вправі бути законними представниками. На думку С.Я. Хоменка, законними представниками не можуть бути: особи, позбавлені батьківських прав; особи, які спонукали неповнолітнього до вчинення злочину або брали участь у ньому спільно 3 неповнолітніми; особи, які є підозрюваними або обвинуваченими; особи, які мають алкогольну або наркотичну залежність; особи, які страждали на психічні захворювання; недієздатні або обмежено дієздатні особи; інші особи, якщо між їх інтересами й інтересами неповнолітніх $є$ суперечності [7, с. 110]. Частково перегукуються із цим переліком перелік обставин, які б дозволяли усунути або обмежити участь законного представника у кримінальному провадженні, який наводить М.О. Карпенко. Цими обставинами можуть бути недієздатність законного представника; вчинення ним дій, які можуть призвести до несприятливих наслідків для неповнолітнього (наприклад, зловживання своїми обов'язками, здійснення психологічного тиску на дитину з метою зміни своїх показань тощо); вчинення законним представником проти підлітка протиправних дій [4, с. 89].

Ми переконані, що до вказаного переліку необхідно додати ще одну обставину, коли вказані особи перебувають у конфліктних відносинах із неповнолітнім і останній не бажає, щоб та чи інша особа була представником його інтересів. Момент набуття особою процесуального статусу законного представника у кримінальному судочинстві пов'язаний із залученням його до участі у кримінальному провадженні відповідним повноважним суб'єктом, який здійснює це провадження. Про залучення законного представника дізнавач, слідчий, прокурор виносить постанову, а слідчий суддя, суд постановляє ухвалу, копія якої вручається законному представникові. Саме після цього особа набуває свого процесуального статусу законного представника та може реалізовувати свої права й обов'язки [6, с. 367].

Оскільки законний представник бере участь у кримінальному провадженні для реалізації своєї функції щодо захисту прав та інтересів неповнолітнього на всіх стадіях кримінального процесу, то в разі допуску до участі у провадженні йому повинні бути роз'яснені права [7, с. 110]. Також необхідно пам'ятати і про його обов'язки, які закріплені частково у КПК України [1, с. 188]. В.Г. Пожар вважає за необхідне ознайомлення законного представника з процесуальними правами та обов'язками шляхом вручення останньому пам'ятки про його процесуальні права та обов'язки одночасно з ї роз'ясненням, аналогічно як підозрюваному чи обвинуваченому [6, с. 368]. 
Слід відзначити, що залучення законного представника підозрюваного чи обвинуваченого є обов'язковим за наявності підстав, зазначених у ч. 1 ст. 44 КПК України [2]. Тому у випадках відсутності у потерпілого, підозрюваного чи обвинуваченого батьків, усиновлювачів, опікунів, піклувальників, інших повнолітніх близьких родичів чи членів сім'ї, дізнавач, слідчий, прокурор чи суд зобов'язані залучити представників органів опіки і піклування як законних представників. Крім того, у разі, якщо дії чи інтереси законного представника суперечать інтересам особи, яку він представляє, за рішенням дізнавача, слідчого, прокурора, слідчого судді, суду такий представник замінюється іншим із числа осіб, зазначених у ч. 2 ст. 44 КПК України. Таке рішення оформлюється у вигляді постанови (ухвали) і має бути мотивоване. Отже, законний представник, який діє всупереч законним інтересам осіб, яких він представляє, неважливо 3 яких мотивів, чи то з помсти, чи то з корисливих мотивів або інших особистих інтересів, не може бути представником. В.Г. Пожар поділяє думку процесуалістів, які виступають тільки за добровільну участь представника у провадженні [6, с. 367].

Більшість процесуалістів дотримується думки про те, що така згода непотрібна. Однак на практиці інколи виникають проблеми 3 приводу бажання (небажання) обраного неповнолітнім підозрюваним законного представника бути допущеним до участі в кримінальному процесі. На думку Г.М. Міньковського, участь законного представника в кримінальному судочинстві є не тільки його правом, а й обов'язком.

В такому разі потребує аналізу питання, чи необхідна згода неповнолітнього для участі в кримінальному провадженні його представника. У процесі життя і розвитку неповнолітнього його відносини з батьками та іншими особами, які можуть бути наділені повноваженнями законних представників, складаються по-різному. Саме прихильність, взаєморозуміння, довіра неповнолітнього до законного представника є прямим шляхом до їх активної, спільної та узгодженої участі в процесуальній діяльності, що, зрештою, сприяє забезпеченню прав і захисту законних інтересів неповнолітнього підозрюваного. Якщо неповнолітній перебуває під опікою установ та організацій, також можна надати неповнолітньому можливість вибору законного представника з числа адміністрації, працівників цієї установи чи організації, педагогічному складу. Законодавчо це не передбачено. Аналізуючи Кримінальний процесуальний кодекс Російської Федераціï, а саме ст. 48 «Законні представники неповнолітнього підозрюваного та обвинуваченого», у якій чітко передбачена обов'язкова участь законних представників, можна стверджувати, що неповнолітній не може відмовитися від допомоги законного представника, а також на призначення та здійснення будь-яких дій законним представником згода неповнолітнього не потрібна [3].

Приймаючи рішення про допуск особи як законного представника до участі у провадженні, дізнавач, слідчий, прокурор у кожному випадку повинен з'ясовувати, чи не існує конфлікту інтересу між його інтересами та інтересами підлітка. Крім того, на думку М.О. Карпенка, доцільно на законодавчому рівні передбачити положення про можливість повного 
усунення законного представника від участі у провадженні, заміну його іншим або обмеження участі в провадженні певних процесуальних дій, якщо його діяльність суперечить інтересам неповнолітнього. В інших випадках права законного представника не можуть бути обмежені, оскільки він $є$ самостійним учасником кримінального процесу. Наведені думки повністю узгоджуються з приписами Мінімальних стандартних правил, що стосуються відправлення правосуддя щодо неповнолітніх. Згідно з п. 15.2 правил, батьки чи опікуни мають право брати участь у судовому розгляді, і компетентний орган влади може вимагати їх присутності в інтересах неповнолітнього. Однак компетентний орган влади може відмовити їм у такій участі, якщо є підстави вважати, що це необхідно в інтересах особи, яка не досягла вісімнадцяти років [4, с. 89]. В ст. 488 КПК України зазначено, що «батьки або інші законні представники неповнолітнього беруть участь у кримінальному провадженні за участю неповнолітнього підозрюваного чи обвинуваченого», а також в ч. 3 вказаної статті передбачено, що «у виняткових випадках, коли участь законного представника може завдати шкоди інтересам неповнолітнього підозрюваного, суд за його клопотанням має право обмежити участь законного представника у виконанні окремих процесуальних чи судових дій або усунути його від участі у кримінальному провадженні і залучити замість нього іншого законного представника» [1, с. 188]. 3 цього положення ми бачимо, що законодавець передбачає можливість надання вибору неповнолітньому підозрюваному після призначення законного представника щодо обмеження участі останнього чи повного його усунення від участі у кримінальному провадженні, тим самим частково узгоджує норми українського закону із приписами міжнародних актів.

У юридичній літературі існує думка, що участь законного представника в допиті неповнолітнього потерпілого, підозрюваного чи обвинуваченого, а також присутність його під час провадження інших слідчих (розшукових) дій є недоцільною, оскільки «багато в чому обмежує можливості дізнавача, слідчого, прокурора у встановленні психологічного контакту, що використовується з метою вибору тактичних прийомів і методів проведення слідчих (розшукових) дій. Це суттєво впливає на обсяг доказової інформації, яку міг би отримати слідчий чи дізнавач від неповнолітнього потерпілого, підозрюваного, обвинуваченого». Участь захисника та законного представника у проведенні слідчих (розшукових) дій може зашкодити тільки в тому разі, коли дізнавач, слідчий чи прокурор не володіє знаннями з дитячої психології, не має навичок у спілкуванні з неповнолітніми та використовує неправомірні методи психологічного впливу (погрози, побої тощо) [4, с. 110].

Аналіз протоколів допитів законних представників як свідків, що був здійснений М.О. Карпенком, дає змогу виявити певні особливості предмету ї показань. Здебільшого вони нічого не повідомляють про факт вчинення злочину. Дізнавач чи слідчий допитує їх про особистість неповнолітнього, умови життя і виховання, про те, як стало можливим, що дитина вчинила злочин. Тобто органи, які здійснюють кримінальне провадження, бачать 
у законному представнику не захисника неповнолітнього підозрюваного, а особу, яка відповідає за його виховання, особу, за відсутності контролю з боку якої стало можливим вчинення злочину підлітком.

Слідчому чи дізнавачу необхідно ретельно вивчати особистість законного представника, характер його відносин із неповнолітнім. Це зумовлено тим, що законним представником має виступати особа, як володіє достовірними відомостями про процес формування особистості неповнолітнього, його поведінку, відносини в сім'ї, школі, на роботі, про умови життя і виховання неповнолітнього, його інтелектуальний і фізичний розвиток, нахили, індивідуальні особливості характеру. Ці особи часто у змозі повідомити про мотиви і причини вчинення злочину, про дорослих підбурювачів та інших співучасників. Тому правильною $є$ тактика дізнавачів, слідчих, прокурорів, суддів, які також з'ясовують і думку законного представника щодо подальшого догляду за неповнолітнім, процесу його перевиховання [4, с. 94]. Отже, участь законного представника у процесі досудового розслідування як представника інтересів неповнолітнього має базуватися на взаємній ї згоді.

Висновки. У чинних законодавчих актах термін «законні представники» використовується як родове поняття, до якого включаються батьки, усиновлювачі, батьки-вихователі, опікуни, піклувальники, прийомні батьки, патронатні вихователі, представники закладів, які виконують обов'язки опікунів, піклувальників. Для запобігання порушенню прав і законних інтересів потерпілих, підозрюваних, обвинувачених, які не можуть самостійно реалізувати свої процесуальні права, законодавець передбачив додаткові можливості дотримання їх прав за допомогою участі у провадженні законних представників.

Підсумовуючи наведене вище, можна сказати, що участь законного представника неповнолітнього потерпілого, підозрюваного чи обвинуваченого є, безумовно, головною гарантією належної охорони прав та законних інтересів цих осіб. Законний представник, який здійснює представництво інтересів неповнолітнього підозрюваного чи обвинуваченого, має співпрацювати із захисником, який здійснює захист його прав та інтересів та разом за допомогою засобів захисту надавати можливість спростувати підозру, виявити обставини, які пом'якшують чи виключають кримінальну відповідальність неповнолітнього. А також, на відміну від законного представника, який може займати у провадженні позицію, яка відрізняється від позиції неповнолітнього підозрюваного чи обвинуваченого, захисник керується лише інтересами підзахисного, тому він має також відстежувати ці негативні прояви зі сторони законного представника та відповідно реагувати на них.

Що ж стосується участі законного представника, то неповнолітній підозрюваний чи обвинувачений, за умови досягнення ним шістнадцятирічного віку, вправі відмовитися від участі такого учасника процесу взагалі, у всіх інших випадках повна відмова від участі законного представника не може бути задоволена, можна лише, враховуючи думку та побажання неповнолітнього підозрюваного чи обвинуваченого, призначити представником особу, якій він довіряє, чи змінити представника, за умови попереднього його обрання. 


\section{Література}

1. Кримінальний процесуальний кодекс України [текст]. Київ: «ентр учбової літератури», 2012. 254 c.

2. Кримінальний процесуальний кодекс України. // Відомості Верховної Ради України (ВВР), 2013, № 9-10, № 11-12, № 13, ст. 88). URL: https://zakon.rada.gov.ua/laws/ show / 4651-17(дата звернення: 23.04.2021.)

3. Уголовно-процессуальный кодекс Российской Федерации: от 18 дек. 2001 г. URL: http:/ / www.consultant.ru/document/cons_doc_LAW_34481. (дата двернення: 23.04.2021.)

4. Карпенко М.О. Особливості провадження в справах про злочини неповнолітніх: монографія. Харків: Видавництво «ФІНИ», 2009. 240 с.

5. Мельникова Є.Б. Ювенальная юстиция. Проблемы уголовного права, уголовного процесса и криминологии: учеб, пособие / Мельникова Є.Б. [2-е изд., испр. и доп.]. М.: Дело, 2001. 272 c.

6. Пожар В.Г. Новели регламентації інституту представництва за новим Кримінальним процесуальним законодавством України / В. Г. Пожар / / Митна справа: науково-аналітичний журнал. 2012. № 5(83). С. 363-368.

7. Хоменко С.Я. Участь законного представника неповнолітнього у кримінальній справі // Науковий вісник Національної академії внутрішніх справ: Науково-теоретичний журнал / МВС України. К., № 3. 2011. С. 109-118.

8. Чурікова І.В. Початок досудового розслідування у кримінальному процесі України / I.В. Чурікова / / Юридичний часопис НАВС. К., 2013. № 2. С. 226-231.

\section{Ано о а ц і я}

Харченко C. B., Симчук A. C. Залучення законного представника у кримінальних провадженнях за участю неповнолітніх осіб. - Стаття.

Становлення України як демократичної правової держави, проголошення людини найвищою соціальною цінністю вимагає вжиття відповідних суспільно-політичних і правових заходів щодо забезпечення прав і свобод людини. Такі заходи особливо важливі для забезпечення прав і свобод такої категорії населення, які в силу свої вікових особливостей, психофізіологічної незрілості й соціально-психологічної адаптованості неспроможні самостійно захистити свої порушені чи спірні права або реалізувати процесуальні повноваження. Серед таких осіб найбільш незахищеною категорією суспільства є саме неповнолітні. Тому їхні права та інтереси перебувають під постійною пильною увагою як законодавців, так і правоохоронних органів, прокуратури, суду.

Досудове провадження у кримінальних справах щодо неповнолітніх, які вчинили правопорушення, а також неповнолітніх, котрі є потерпілими від правопорушення, здійснюється в Україні в межах повноважень єдиної системи процесуальної діяльності органів досудового слідства й прокуратури. Воно спрямоване на досягнення єдиних цілей кримінального процесу і грунтується на загальних принципах кримінального судочинства, однак має й певні особливості.

Неповнолітні особи, які потрапили у сферу кримінального процесу, у силу своїх вікових особливостей потребують посилення своєї правової захищеності, застосування до них особливих правил під час провадження й створення для них додаткових процесуальних гарантій. Однією з форм правого захисту є подвійне представництві інтересів неповнолітнього в суді - його законним представником і захисником (адвокатом).

На відміну від захисника, законні представники захищають інтереси неповнолітнього не через призму виконання професійної діяльності, а насамперед через загально-правову відповідальність за своїх неповнолітніх дітей з урахуванням морально-етичних аспектів виховання.

У статті висвітлено нормативно-правове регулювання проведення слідчих (розшукових) дій за участю неповнолітніх учасників у кримінальному процесуальному законодавстві України, зокрема обов'язкового залучення законного представника. Підкреслюється значення дотримання процесуальної форми за умов проведення слідчих (розшукових) дій за участю неповнолітніх учасників кримінального провадження.

Ключові слова: розслідування, гарантії, слідчі (розшукові) дії, нормативно-правове регулювання, процесуальна форма, неповнолітній учасник, потерпілий, підозрюваний, обвинувачений, кримінальне судочинство. 


\section{$\mathrm{S} \mathbf{u} \mathrm{m} \mathrm{m}$ a $\mathbf{r} \mathrm{y}$ \\ Kharchenko S. V., Simchuk A. S. Involvement of a legal representative in criminal proceedings involving minors. - Article.}

The formation of Ukraine as a democratic state governed by the rule of law, the proclamation of man as the highest social value requires the adoption of appropriate socio-political and legal measures to ensure human rights and freedoms. Such measures are especially important to ensure the rights and freedoms of this category of the population, which due to their age, psychophysiological immaturity and socio-psychological adaptability are unable to independently protect their violated or disputed rights or exercise procedural powers. Among such persons, the most vulnerable category of society are minors. Therefore, their rights and interests are under constant close attention of both legislators and law enforcement agencies, prosecutors, courts.

Pre-trial proceedings in criminal cases against juveniles who have committed offenses, as well as juveniles who are victims of offenses, are carried out in Ukraine within the powers of the unified system of procedural activities of pre-trial investigation bodies and the prosecutor's office. It is aimed at achieving common goals of the criminal process and is based on the general principles of criminal justice, but also has certain features.

Due to their age, juveniles who have entered the sphere of criminal proceedings need to strengthen their legal protection, apply special rules to them during the proceedings and create additional procedural guarantees for them. One of the forms of legal protection is the double representation of the interests of a minor in court - his legal representative and defense counsel (lawyer).

Unlike a lawyer, legal representatives protect the interests of a minor not through the prism of professional activity, but primarily through the general legal responsibility for their minor children, taking into account the moral and ethical aspects of education.

The article covers the legal regulation of investigative (search) actions with the participation of juvenile participants in the criminal procedure legislation of Ukraine, in particular the mandatory involvement of a legal representative. The importance of observance of the procedural form under the conditions of conducting investigative (search) actions with the participation of juvenile participants in criminal proceedings is emphasized.

Key words: investigation, guarantees, investigative (search) actions, normative-legal regulation, procedural form, juvenile participant, victim, suspect, accused, criminal proceedings. 